\title{
Impacts of Agricultural Practices and Tourism Activities on the Sustainability of Telaga Warna and Telaga Pengilon Lakes, Dieng Plateau, Central Java
}

\author{
Sudarmadji ${ }^{*}$ and Hermin Pudjiastuti ${ }^{2}$ \\ ${ }^{1}$ Department of Environmental Geography, Faculty of Geography, Gadjah Mada University, \\ ${ }^{2}$ Environmental Study Program, Graduate School, Gadjah Mada University
}

\begin{abstract}
Telaga Warna and Telaga Pengilon are two volcanic lakes in the Dieng Plateau offer some unique phenomena which are interested for tourists to visit. Telaga Warna and Telaga Pengilon are located side by side in the Dieng Palteau. Those two lakes also have specific ecosystem which differ to other lakes. However as land use in the surrounding area is now gradually changing, the lake is now facing to environmental degradation. The land use in the surrounding area is for intensive agricultural which main crops are vegetable, especially potatoes. Meanwhile, the number of tourist visiting those two lakes is increasing; it may also give some impact to the lake environment. This research aims to study the impacts of agricultural practices and tourism activities to the lake environmental which lead to the environment sustainability of the lakes. The field survey was conducted to collect some data on lakes characteristics, agricultural and tourism activities. Some interviews to local people and tourists were also conducted. Some water and sediment samples were collected followed by laboratory analyses. Some secondary data from previous study was also collected. Data analysis was conducted based on qualitative and quantitative techniques. The study found that agricultural practices of potatoes plantation uses water from the Telaga Pengilon to irrigate the plant by pumping out the water using water pump and distributes the water over the plantation area. Agricultural practices lead to soil erosion, which contribute sediment to the lake carried by surface runoff. Therefore, the volume of lakes is gradually decreasing. The use of fertilizer in the agricultural practice contribute nutrient into the lake carried by surface runoff, leading to the eutrophication, due to the excess used of fertilizer. The study concludes that agricultural practices and tourism activities have some positive economic impacts to the local community, however it also give some adverse affects on the lakes, both quantitatively and qualitatively. The volume of lakes is gradually decreasing due to sedimentation. In the long term periods the lake may not be interesting object for tourism.
\end{abstract}

\section{Introduction}

Around the world a lot of lakes have some environment problem such as sedimentation and water pollution [1-3]. Telaga Warna and Telaga Pengilon are two lakes which are located within one of the most strategic complexes in the Dieng Plateau. Both of these lakes are well known among tourists, especially local tourists. However, many foreign tourists also come to visit the lakes. Foreign tourists do not merely visit the lake, because actually the uniqueness of the Telaga Warna and Telaga Pengilon are not separated by the uniqueness of the Dieng Plateau region as a tourist objects. Telaga Warna has colorful water caused by the minerals and the organisms contained, combined with the sunlight that strikes the lake and then reflected, thus giving a colorful effect. Telaga Pengilon has a clear water, make the lake looks like looks like a mirror. As volcanic lake, these two lakes have some uniqueness like other volcanic lakes [4].

The exotic panoramic of Telaga Warna and Telaga Pengilon make many tourists to visit, therefore, some opportunities for local governments and local community to develop them as natural attractions, which can increase local revenue, as well as expected to improve the welfare of the surrounding community. However, on the other hand, the increasing number of tourists visiting the Talaga Warna and Telaga Pengilon has also some negative impacts to occur, due to the behavior of tourists who are not environmentally friendly. The tourist's activity may create some wastes that may pollute the environment [5].

On the other side the catchment area of Telaga Warna and Telaga Pengilon has been gradually

Corresponding author: sudarmadji@ugm.ac.id 
changed and developed for potato cultivation. The changes of land use of the surrounding area into agricultural area (with potato cultivation) bring economic benefits to the community [6]. The changes of land use of the surrounding area into agricultural land produce sediment, and contribute part of the residual fertilizer and pesticide into the lake [7]. Therefore, the lakes environment will gradually threaten that make the lakes no longer attract tourists to visit. Based on the above background, this research aims to: 1) identify the potential of Telaga Warna and Telaga Pengilon as a natural tourism object either at present or their development in the future. 2) Analyze the activities of the surrounding community on the possibility of decreasing the environmental quality of the Telaga Warna and Telaga Pengilon,

\section{Methods}

\subsection{Research Location}

The research was conducted in Telaga Warna and Telaga Pengilon, Dieng Plateau; administratively the lakes are located in Wonosobo District (Figure 1.)

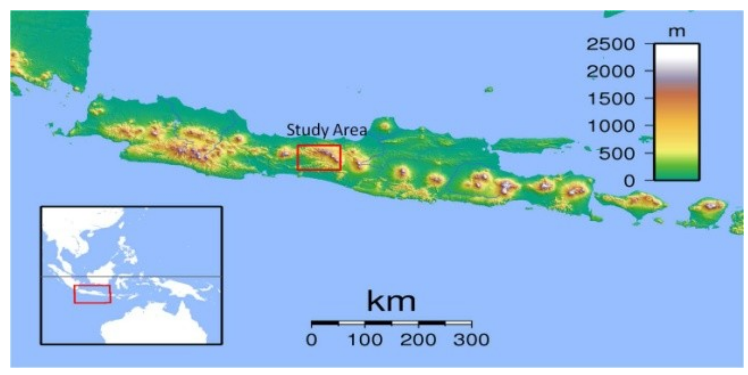

Fig. 1. Research Location

\subsection{Materials and Tools}

a. Map of Wonosobo District of 1:50.000

b. Photographic Map scale 1: 100.00 Wonosobo and Banjarnegara regencies related to the location of the lake;

c. Geomorphology map scale 1: 100,000 Wonosobo and Banjarnegara regencies related to the location of the lake and its catchment area;

d. Geological Map scale 1: 100,000 Wonosobo and Banjarnegara regencies related to the lake location;

e. Maps the location of tourism objects of Wonosobo and Banjarnegara regencies is obtained from previous research, including from the Tourism Office, the local Public Works Department;

f. GPS and Satellite Imagery; g. A set of instruments for water sampling $(\mathrm{pH}$ meter, EC-meter) water sample bottle;

h. Questionnaires for interviews with local residents as well as local community leaders who use water from the lake and tourists who visit the lake, both local and foreign tourists;

I. A set of computer units to perform data analysis.

\subsection{Field Work and Data Collecting}

a. Determine the location of the studied lake using Satellite Imagery.

b. Conduct observations of lake conditions and measurements and taking necessary water samples

c. Conducting interviews with residents and community leaders to find out how people use the lake, manage including how to conserve lakes;

d. Conducting interviews with local tourists and foreign tourists

e. Conducting a laboratory analysis of the samples taken to determine the water quality

\subsection{Data Analysis}

a. Analyzing the spatial presence of natural lakes is associated with environmental conditions as well as other activities around it.

b. Processing and analyzing the results of interviews to obtain the way of the community to manage the lake, especially related to the culture of the local community and associated with tourism activities.

\section{Result And Discussion}

\subsection{Potency of Telaga Warna and Telaga Pengilon}

Telaga Warna and Telaga Penggilon both located in Dieng Plateau, Wonosobo District. Many of the attractions associated with the two lakes, however, this research focused on the lakes as volcanic lakes with all of the characteristics and uniqueness. Nevertheless, the surrounding areas where the community conducting activities that likely to affect the condition of the two lakes are also studied. Telaga Warna and Telaga Color potential in general can be seen from Satellite Imagery (Figure 2). The two lakes appear to differ, in which the Color Lake shows a brighter color whereas Pengilon's lake shows a darker appearance. Both lakes are surrounded by a densely vegetal cover, while in a distance from the lakes the area is already covered by agricultural land and settlements 


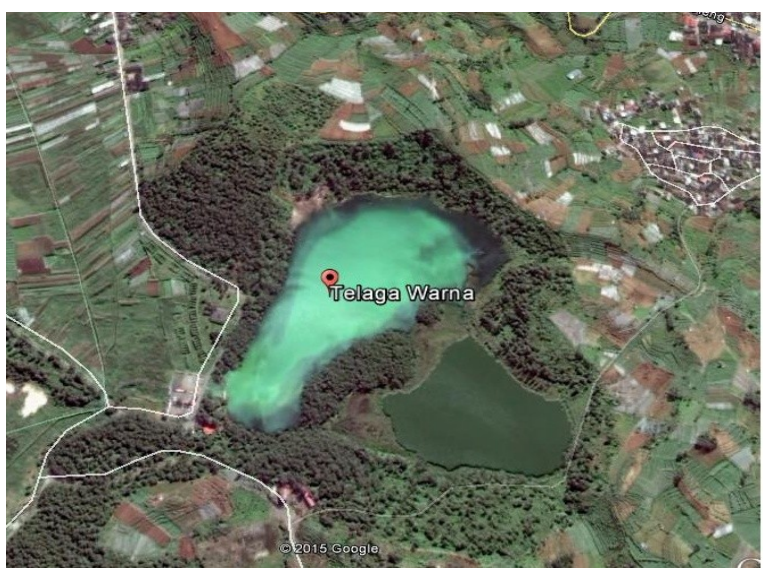

Fig. 2. Telaga Warna and Telaga Pengilon from Satellite Imagery (Google earth, 6th Dec. 2015)

The Telaga Warna when viewed closely shows the calm and cool atmosphere provided by Telaga Warna and Telaga Pengilon due to the charm of its own natural beauty.
The tourist objects close to Telaga Warna and Telaga Pengilon are as follows: 1). Bukit Sidengkeng, 2). Sikendang Crater, 3). Semar Cave, 4). Well Cave, 5). Pond in Sumur Cave, 6). Jaran Cave, 7). Batu tulis. 8). Mliwis Hill, 9). Wlingi Grass.10). Lake Pengilon, 11). Mandar Batu, 12). Rest Area of Bumi Pertolo. These objects are mostly unique volcanic formations that become the main attraction (caves, craters, even flora and fauna). Very interesting color of the lake water is partially whitish, greenish, bluish, and yellowish due to the sulfur and algae and content and because of the reflection of sunlight (Figure 3, right). The silver colors because of the calm looks like a big mirror. There is also a crater that emits sulfuric gas (Figure 3 , left). The potency of Telaga Warna has been supported by facilities such as information boards, offices, parking areas, tour guides, flying fox, and spots to rest and walking tracks around the lake (Figure 4). However, the facility has not been supported with adequate maintenance.

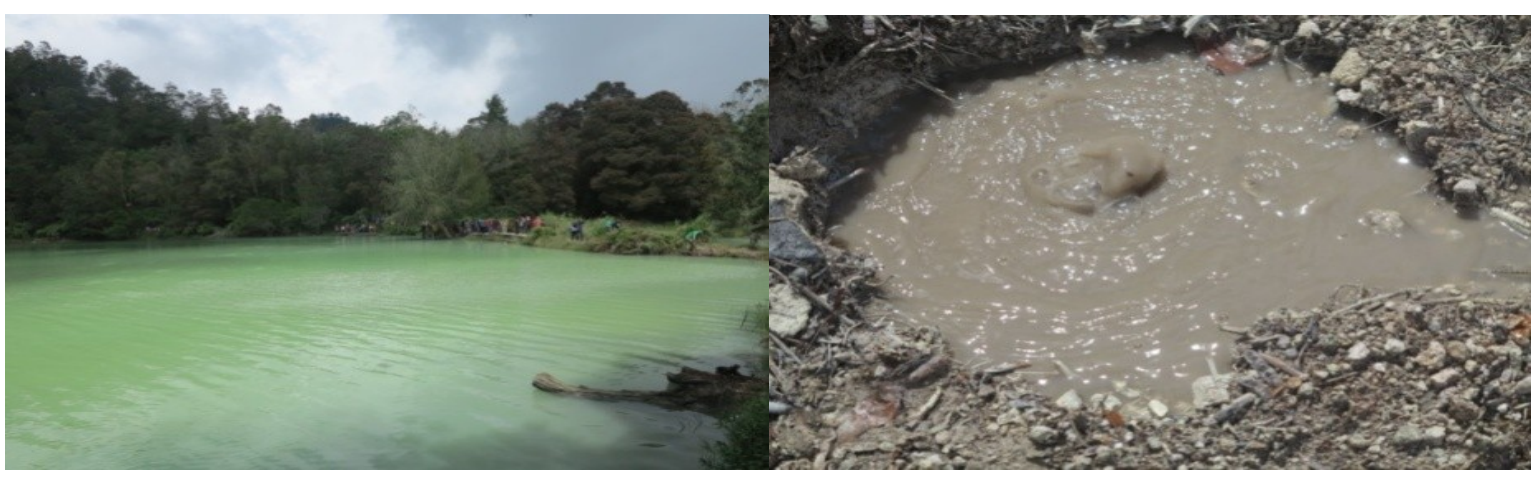

Fig. 3. Yellowish Color of Telaga Warna (Left) and Sikendang Crater (Right) as Unique Tourism Objects (Doc. 2015)
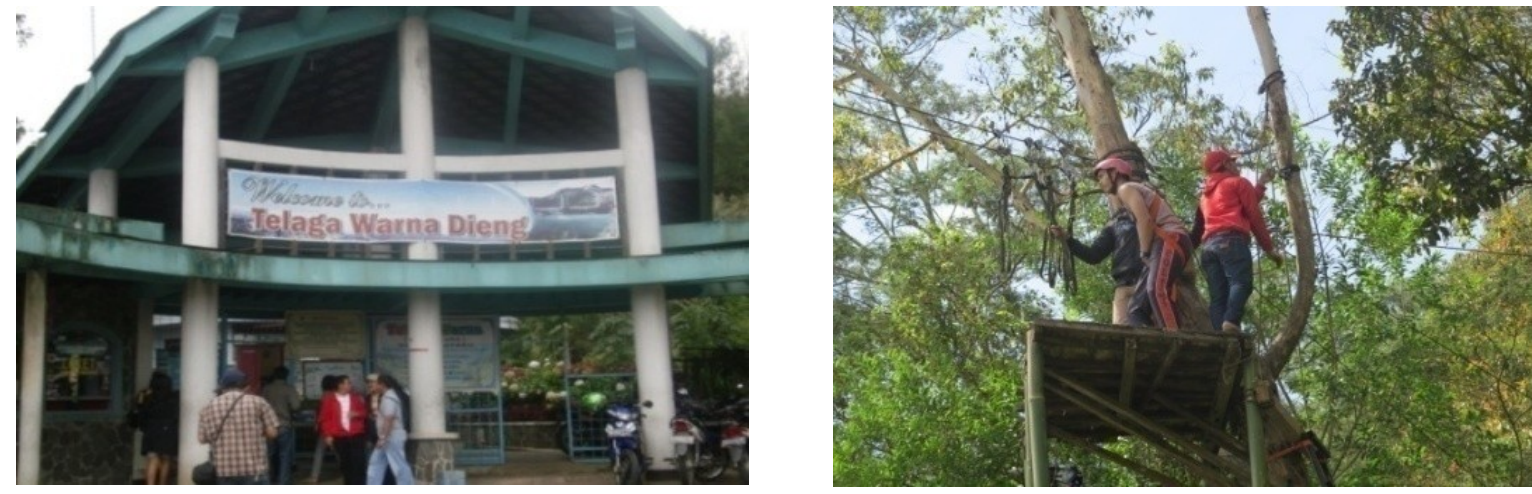

Fig. 4. Supporting Facility and Flying Fox (Doc. 2015)

\subsection{Community Activities around Telaga and Tourists}

The local people mostly work as farmers with main vegetable crops, mainly potatoes (Figure 5). The figure shows a preparation for planting potatoes that make the soil in such a way to create soil erosion. In irrigating the potatoes plants the water of the lake is pumped up using water pump and distributes the water to their farming area with pipes (Figure 6).

The development of Telaga Warna as natural tourist attractions, make some local people to have some new jobs to support tourism activities. Culinary business and selling souvenirs are open, 
and utilized by the local community. Culinary shops and stand of souvenirs are found around Telaga Warna. Similarly, the profession becomes parking operator, tour guide is also open (Figure 7). This means that the development of Telaga Warna provides a positive impact for the surrounding community, in the form of opening of business fields and increasing revenue, not only to the local government, but also for the surrounding community.

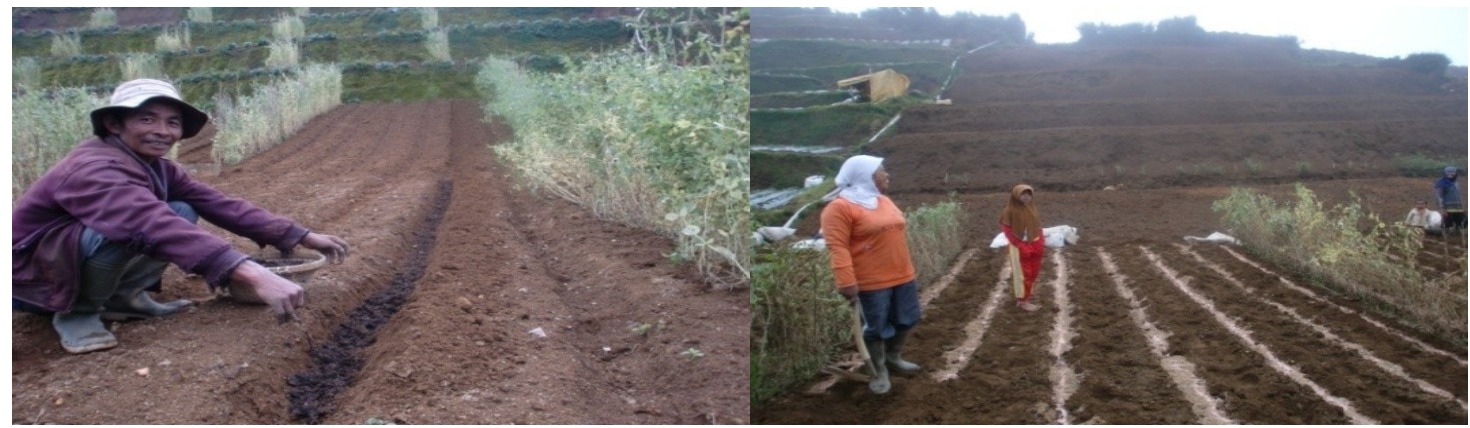

Fig. 5. Preparing Land for Potatoes Plantation (Doc. 2015)

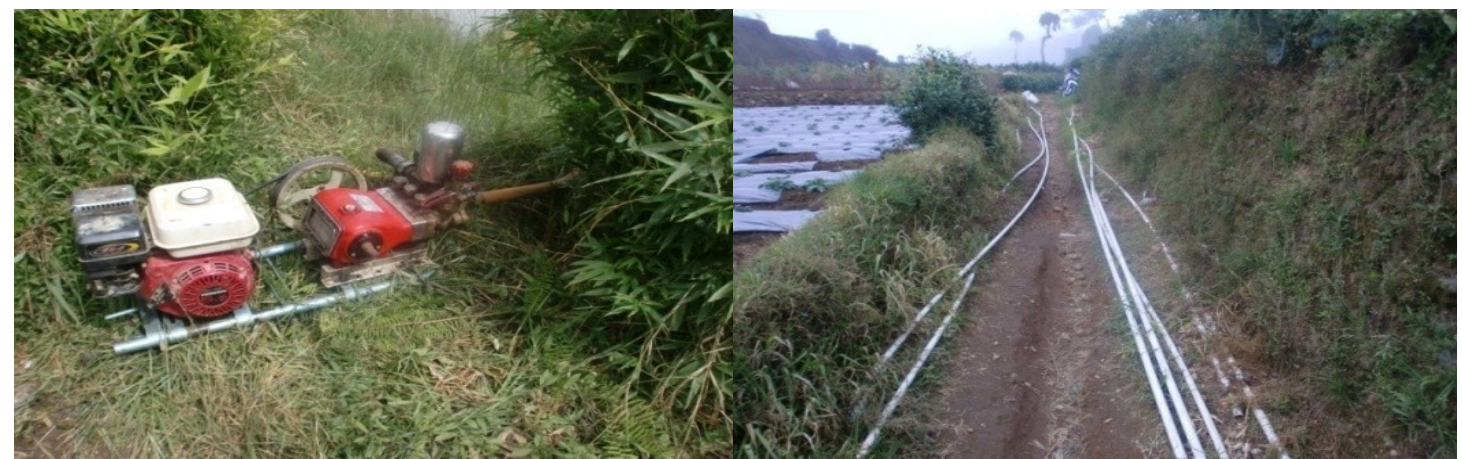

Fig. 6. Irrigation Facilities (water pumps and pipes) (Doc. 2015)
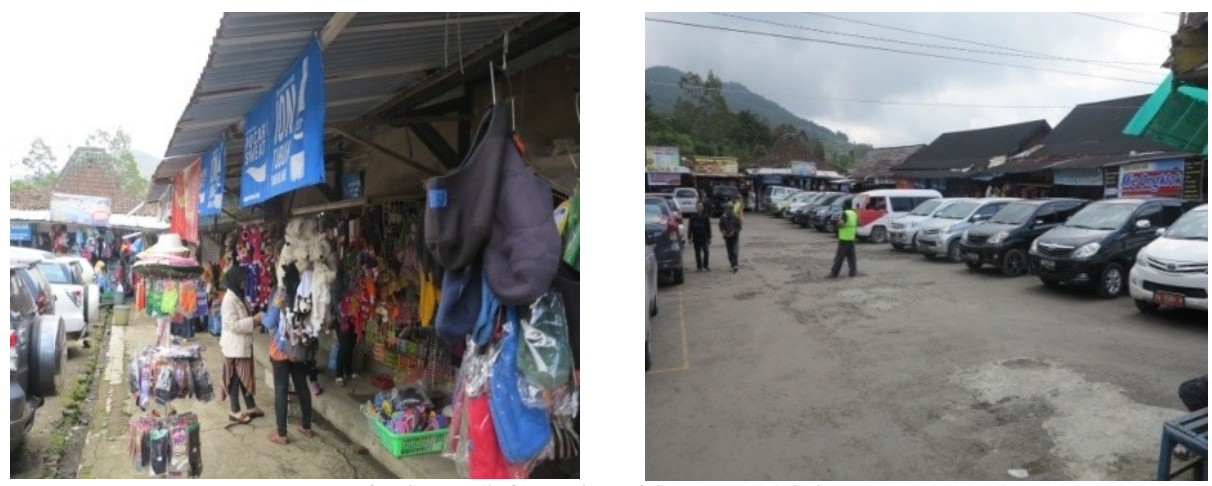

Fig. 7. Souvenir shops (left) and Parking Area (right) (Doc, 2015)



Fig. 8. Tourists activities in the Jogging Track (Doc. 2015) 
Tourists who visit Telaga Warna can perform various activities, from just relaxing to enjoy the beautiful scenery and atmosphere of Telaga Warna and Telaga Pengilon, enjoy the uniqueness of the natural phenomenon around Telaga Warna, walking around the lake through the jogging track, or trying the flying fox (Figure 8).

\subsection{Environmental Impacts}

The development of Telaga Warna as a natural tourist attraction has provided many benefits and poses a positive impact for the local government and the surrounding community, especially from the economic point of view i.e. the increasing of income and the opening of business opportunities [5, 8]. However, tourism activities can also cause negative impacts to the environment, although it should be noted that the negative impacts experienced by Telaga Warna not only comes from tourism activities.

Local activities, such as agricultural activities and other daily activities, also generating waste, disposing into the environment, and can cause environmental impacts $[9,10]$. Agricultural activities of potato cultivation in the surrounding area of Telaga Warna increase soil erosion which further affects sedimentation in Telaga Warna. Although there is no erosion measurement yet, but the effect of sedimentation in Telaga Warna is already visible (Figure 9). The use of fertilizers and pesticides has also affected water quality in Telaga Warna and Telaga Pengilon; it appears that in some places water plants began to grow with "fertile", which in turn cause the shrinking volume of Lake Color and Telaga Pengilon as also occur in other lakes $[9,10$, $11]$.

Nitrate concentration in Telaga Pengilon is higher than those in Telaga Warna, indicates that some impact of agicultural activities have occured.

Water quality data from both Telaga appear to be much different, especially from the $\mathrm{pH}$ and TSS parameters. The $\mathrm{pH}$ at Telaga Warna indicates that the water of the lake is acidic with high TSS, while Telaga Pengilon exhibits a lower of TSS (Table 1 and 2).
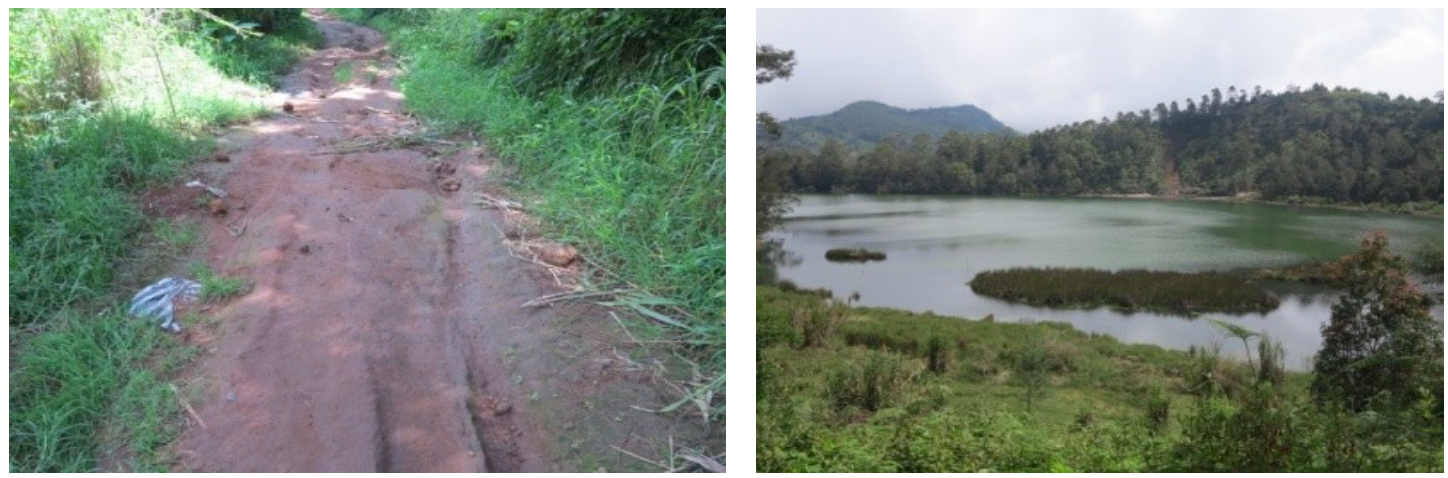

Fig. 9. Jogging Tracks as Sediment Source (left) and Sediments in Telaga Warna (right)

Table 1. Water Quality Analysis of Telaga Warna

\begin{tabular}{lcccc}
\hline Parameters & Unit & \multicolumn{3}{c}{ Number of Water } \\
& & \multicolumn{3}{c}{ Sample } \\
\cline { 3 - 5 } & & TW & TW & TW \\
& & A 2 & A 3 & A 5 \\
\hline Temperature & ${ }^{\circ} \mathrm{C}$ & 25.9 & 27.6 & 27.3 \\
EC & $\mu \mathrm{S} / \mathrm{cm}$ & 1497 & 552 & 1384 \\
$\mathrm{pH}$ & - & 2.90 & 4.66 & 2.87 \\
Nitrate & $\mathrm{mg} / 1$ & 0.275 & 0.402 & 0.466 \\
BOD & $\mathrm{mg} / 1$ & 0.37 & 0.39 & - \\
COD & $\mathrm{mg} / 1$ & 1.46 & 0.74 & 6.67 \\
Phosphate & $\mathrm{mg} / 1$ & $\leq 0.02$ & $\leq 0.02$ & $\leq 0.02$ \\
Coliform & MPN/100ml & 7 & 11 & 7 \\
\hline Sources: Laboratory Analysis & & &
\end{tabular}

Table 2. Water Quality Analys is of Telaga Pengilon

\begin{tabular}{lcccc}
\hline Parameters & Unit & \multicolumn{3}{c}{$\begin{array}{c}\text { Number of Water } \\
\text { Sample }\end{array}$} \\
\cline { 3 - 5 } & & TPA & TPA & TPA \\
& & $\mathbf{1}$ & $\mathbf{2}$ & $\mathbf{3}$ \\
\hline Temperature & ${ }^{\circ} \mathrm{C}$ & 25.7 & 26.0 & 25.6 \\
EC & $\mu \mathrm{S} / \mathrm{cm}$ & 202 & 176 & 176 \\
pH & - & 8.36 & 8.30 & 8.88 \\
Nitrate & $\mathrm{mg} / 1$ & 1.616 & 1.041 & 0.339 \\
BOD & $\mathrm{mg} / 1$ & 0.79 & 0.49 & 0.65 \\
COD & $\mathrm{mg} / 1$ & 6.42 & 12.59 & 10.85 \\
Phosphate & $\mathrm{mg} / 1$ & $\leq 0.24$ & $\leq 0.11$ & $\leq 0.11$ \\
Coliform & $\mathrm{MPN} / 100 \mathrm{ml}$ & 7 & 7 & 11 \\
\hline Sources
\end{tabular}

Sources: Laboratory Analysis 
In Telaga Warna volcanic activity is still occurring intensively. This water is not good for irrigation uses. Tourist activities can also have impacts on Telaga Warna and Telaga Pengilon. Jogging track land is vulnerable to soil erosion, and it contributes to the sedimentation of the lake.

Tourist's activities can contribute wastes, which is often discarded in the improper place. This may also occur in Telaga Warna and Telaga Pengilon, although warning signs have been installed and garbage disposal bean has been provided (Figure 10). It is also important to note that some vandalism is observed in some places.

Based on the results of observation it is very clear that Telaga Warna and Pengilon have some potencies to be developed in term of tourist attraction. The development can include the addition of tourism supporting facilities, such as the road to the lake Telaga Warna, facilities in the Telaga Warna such as places or spots to enjoy the view, camping ground, and adequate office. Toilets should also be provided adequately with good maintenance. Native plants in this area may be offered as a tourist attraction that if it is managed properly. If in this area a botanical park with a typical plant is managed properly, it is something can attract for tourists to visit. In this case, the involvement of local community is very important $[8,12,13]$.

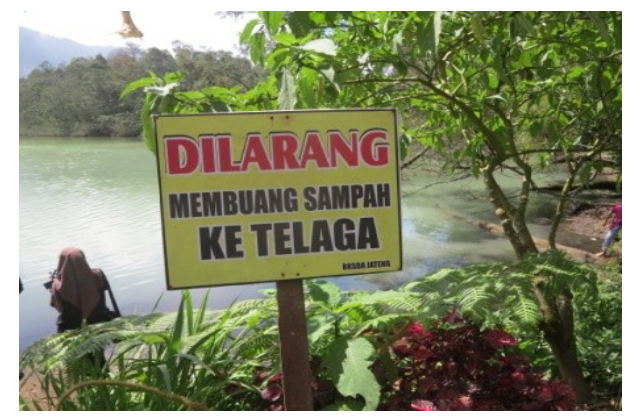

Fig. 10. Warning Sign in Telaga Warna (Doc, 2015)

The negative impacts of tourism activities and local agricultural activities, especially originated from potatoes farming. It will threaten the preservation of Telaga Warna and Telaga Pengilon, mainly due to high sedimentation rate. The sedimentation that has occurred, decreased the volume of the lake, is apparent during the dry season (Figure 11). The result of sediment grain analysis obtained shows that the sediment contained in Telaga Warna and Telaga Pengilon has the similar characteristics with the soil located on either right or around the lake. This means that the land around the lake has create high erosion followed by transporting sediment material into the lake. Some solid wastes is also resulted from tourism activities, all of which must be controlled (if not preventable) to maintain the sustainability of natural attractions of Telaga Warna and Telaga Pengilon.

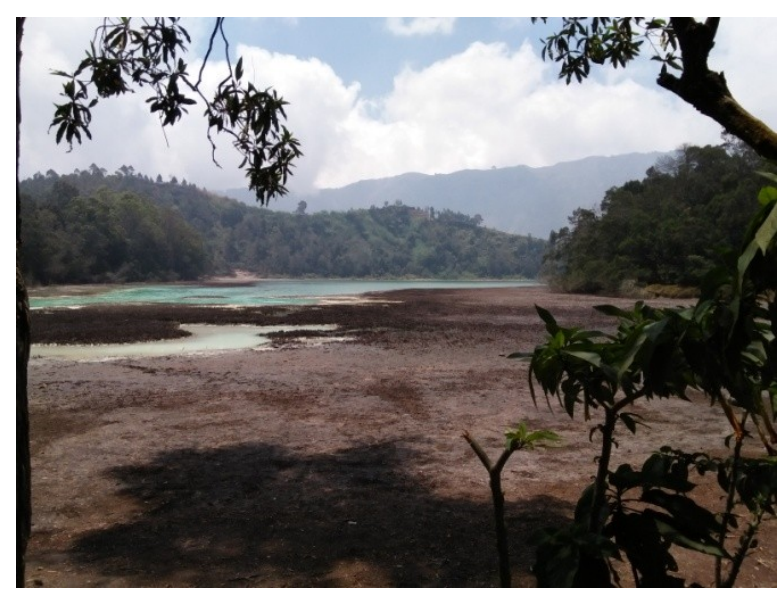

Fig. 11. Sediment to Decrease the Volume of Telaga Warna (Doc. 2015)

\section{Conclusions}

Telaga Warna and Pengilon is a volcanic lake that becomes main attraction in Dieng area. Mineral content and algae that vary along with the reflection of sunlight produces unique and natural colors for tourists to enjoy. The famous Telaga Pengilon has a very clear. Other uniqueness of the two lakes is that, even though they located side by side, the water color is significantly difference. The uniqueness of the lakes is a potential for tourism attraction, therefore it should be developed to maintain the sustainability of Lake Color and Pengilon as natural tourism attractions.

Community activities around Telaga Warna and Pengilon are very diverse. The existence of Telaga Warna and Pengilon as a tourist attraction has some positive impacts, because it opens the opportunities to find new job that can increase people's income, such as traders, tour guides or parking operator. Telaga Warna and Telaga Pengilon is the source of water used by the community for the irrigation of its plants.

However, there are some community activities that have negative impact to Telaga Warna and Pengilon. Potato farm activity around the steep slopes contributes considerably to the sedimentation. Potato cultivation results in soil erosion, fertilizers and pesticides dissolved into the lake thus degrading the water quality of the lake. Dissolved nutrient in water originated from the rest of the fertilizer may cause blooming of water plants in some places $[6,9,14]$. It affects the light penetration and dissolved oxygen levels in the waters, so that organisms in the water such as fish are difficult to survive. The farmers take water from the lake for irrigation using water pumps. The 
management prohibits the surrounding community from using water for irrigation sources. Although there is a limitation from using water, but the farmers do not stop from pumping up the water.

As a leading tourist attraction for Wonosobo Regency, Telaga Warna and Telaga Pengilon cannot be developed independently without linking with other tourism objects. This means that the development of this tourist attraction must be combined with other attractions in an integrated manner, and made a package with other attractions. Community involvement needs to be improved so that the negative impact of the development of this tourism object can be minimized. The development should also consider the risk disasters, as Telaga Warna and Telaga Pengilon are located in an active volcanic area. Natural disasters may occur unpredictably, therefore mitigation is needed. Management of tourist area of Dieng as a whole should also consider, the existence of home stay, restaurant and other facilities such as road connecting tourist objects around the area.

\section{REFERENCES}

1. International Lake Environment Comitee (ILEC) Foundation. How can We Stop Degradation of the World's Lake Environment. ILEC, Shiga Japan.

2. Kowenje, C. O. and Agunya, E.O. Chemical Polution of Lake Victoria A Case Review of Winam Gulf. Proceeding Seminar on Five Years of Exceed (2014)

3. Ministry of Environment of the Republic of Indonesia. Indonesian Lake Management. The Indonesian Movement for lake Ecosystem Conservation and Rehabilitation. Ministtry of Env. of Republic of Indonesia, Jakarta. (2014)

4. Setiawan, S., Wibowo, H., Santosa, A. B., Nomosatryo, S., dan Yuniarti, I. Karakteristik Danau Asal Vulkanik, Studi Kasus: Danau Tolire, Pulau Ternate. Limnotek, Vol. 21. No. 2. pp. 103-114. (2014)

5. Sudarmadji, Eko Haryono, Darmakusuma Darmanto dan Widyastuti. Pengembangan Wisata Alam: Implikasinya terhadap Lingkungan Hidup dan Risiko Bencana yang
Dihadapi di Daerah Istimewa Yogyakarta. Research Report. Sekolah Pascasarjana UGM, Yogyakarta. (2013)

6. Rusiah, M. , Satya, N and Wahyudin, A. Dampak Aktivitas Pertanian Kentang terhadap Kerusakan Lingkungan Obyek Wisata Dataran Tinggi Dieng. PELITA, Vol. 1, No. 1, August. (2005)

7. Sudarmadji. Fungsi Waduk Dalam Ekosistem Daerah Aliran Sungai dan Masalah yang Dihadapi. Proceeding Seminar on Limnology. Fakultas Biologi UGM. (2004)

8. Sudarmadji, Suprayogi, S., Thianton, T.A., dan Werdiningsih. Survey Hidrologi untuk Pengelolaan Sumberdaya Air Berbasis Masyarakat: Kasus di Telaga Towet Desa Girisekar, Kecamatan Panggang, Kabupaten Gunungkidul. Laporan Penelitian, Fakultas Geografi UGM Yogyakarta.

9. Piranti, A.S. Kajian Kriteria Nutrien sebagai Dasar dalam Penilaian Status Tropik Perairan Waduk Mrica Banjarnegara, Jawa Tengah. Disertation. Universitas Gadjah Mada, Yogyakarta. (2012)

10. Wantasen, S. Spasial Ekologi Nitrogen di Danau Tondano, Provinsi Sulawesi Utara. Disertation. Sekolah pascasarjana UGM. Yogyakarta. (2009)

11. Widyastuti, M., Fadilah, L.N., and Rasyadi, F.A. Kajian Potensi Sumberdaya Air Danau untuk Pertanian, Studi di Danau Merdada Kecamatan Dieng, Kabupaten Banjarnegara. Research Report., Fak. Geografi UGM. (2014)

12. Partomo, Mangkuprawiro, S., Hupeis, A. V.S., dan Adrianto, L. Pengelolaan Danau Berbasis Co-Management : Kasus Rawa Pening. Jurnal Pengelolaan Sumberdaya Alam dan Lingkungan. Vol. 1 No.2 pp. 114-119. (2011)

13. Sudarmadji, Slamet Suprayogi dan Setiadi. Konservasi Mataair Berbasis Masyarakat di Kabupaten Gunungkidul untuk Mengantisipasi Perubahan Iklim. Research Report. Sekolah Pascasarjana UGM, Yogyakarta. (2010)

14. Nomosatryo, S dan Lukman. Klasifikasi Trofik Danau Toba, Sumatera Utara. Jurnal Limnotek, Perairan Darat Tropis di Indonesia, Vol. 19. No. 1. pp. 13-21. (2012) 